Dr VLADIMIR PREBILIČ

Associate professor and Chair of the Defense Studies Department

Faculty of Social Sciences at the University of Ljubljana

Dr DAMIJAN GUŠTIN

Director of the Institute of Contemporary History in Ljubljana

assistant professor at the Defense Studies Department

Faculty of Social Sciences at the University of Ljubljana

\title{
INTEROPERABILITY IN PRACTICE: CASE STUDY OF THE SLOVENIAN INDEPENDENCE WAR OF 1991
}

\begin{abstract}
The paper will examine the theory of the interoperability of armed forces through the case of he Slovenian Independence War of 1991. Although defense system interoperability is a well-established concept, there are many obstacles to its implementation. Some defense systems do not deliberately support the idea of interoperability. One such example is the total defense system in SFR Yugoslavia, which is comprised of two defense components: the Yugoslav People's Army (YPA) and territorial defense structures organized by the federal republic. The question of interoperability is highly relevant since the war was fought between the YPA and the defense forces of the newly proclaimed independent state, Slovenia, who were partners in the total defense concept. Due to the clear asymmetry, interoperability offered a great advantage in the independence war. The Slovenian defense forces were combined into three structures: the former militia as an internal security element, the territorial defense as a military component, and the national protection forces as a "civil" defense element. Although each structure had its own command and organizational structure, during the Slovenian War they were combined into a well-structured and organized defense element that achieved victory against a much stronger, better equipped, and better supported army.
\end{abstract}

KEY WORDS: Interoperability, Independence War of 1991, Slovenia, Yugoslavia, Territorial Defence Units of Slovenia, Militia 


\section{THEORY OF INTEROPERABILITY}

The involvement of armed forces in military combat has always been a challenge and should be understood on two levels. The first involves cooperation among individual branches of mainly land forces, while the other features cooperation between different friendly or cooperating armies. A large and partly unsolvable question of interoperability is represented by the absence of standardization within an army. With the emergence of professional armies, this question was at least partly addressed, though the question of the synergistic cooperation of armies remains problematic. Coalition combat, therefore, largely depends on attempts to exercise synergy on the battlefield, and that is largely carried out based on the division of the battlefield and fields of responsibility. Following the industrial revolution and the introduction of telecommunication technologies and modern armament systems, military commanders, and planners were afforded new opportunities for managing armed forces. This was the beginning of what is known as tactical interoperability, which in its essence represents the ability of systems, units, or individuals to operate together when executing assigned tasks. From this top-level perspective, interoperability is a good thing, with overtones of standardization, integration, cooperation, and even synergy.

From this viewpoint, it becomes clear that interoperability represents the most homogeneous and perfect form of military cooperation, which, in content, exceeds the parameters of standardization, integration, and cooperation and should therefore achieve synergistic effects. This also means that the aforementioned processes are prerequisite to the achievement of interoperability, even though they may not necessarily guarantee its realization.

This means that internal interoperability encompasses all levels of military operations, from the tactical to the strategic, from combat to support operations, and between various types of elements ranging from platforms and facilities as well as through communications and supply systems of military units (Moon and Fewell, 2008: 5). Specifically, tactical interoperability would help modern military systems achieve great adaptability, rational operation, and responsiveness to asymmetrical threats. Further, interoperability will enable simpler cooperation in common military operations. Therefore, today's war fighters need defense systems that include tactical operations centers based on command, control, communication, computer, and intelligence (C4I) systems, to be fully interoperable. Only with such interoperability is it possible to deter asymmetric treats, such as terrorism and insurgency operations (Murray, 2008: 54-57). 
Graph 1: Towards interoperability

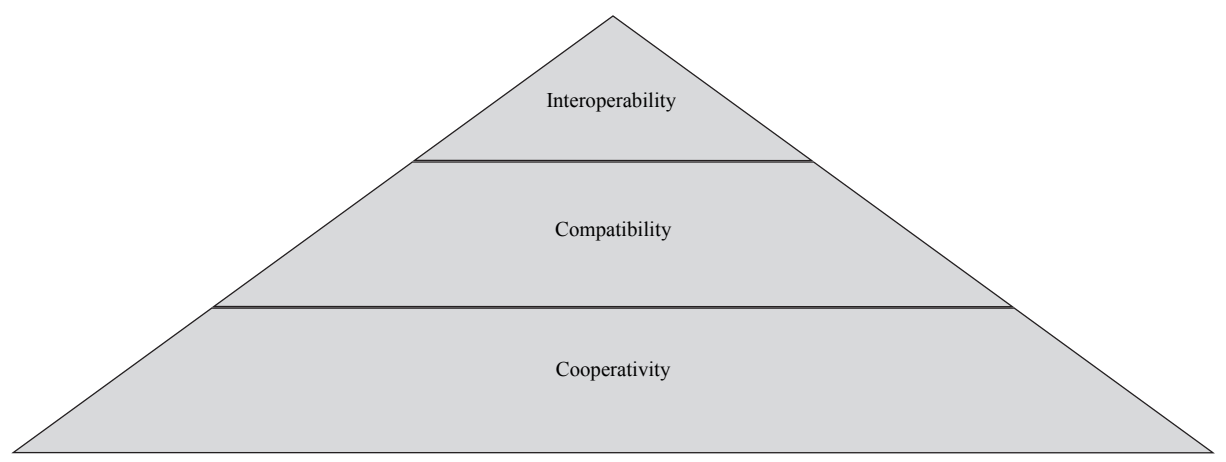

Periods when armed forces are active in the framework of allied operations represent a special challenge, as the North Atlantic Treaty Organization (NATO) has aimed to achieve the interoperability of all armies active under the organization. As a result, the definition of interoperability, which exceeds the frameworks of internal operation and organization of military systems and aims to establish what is called strategic interoperability, was formed. It is perceived as the ability of systems, units, or forces to provide services to and accept services from other systems, units, or forces, and to use these services to enable them to operate effectively together (Wilton, 2006: 1). In this regard, interoperability refers to the ability of forces from different nations to work together effectively given the nature of the forces and the combined military organizational structure acting effective. This combined military organizational structure should enable the degree of similarity of technical capabilities of the forces from different nations, reflecting their fungibility in supporting coalition military goals.

Graph 2: Borders of interoperability

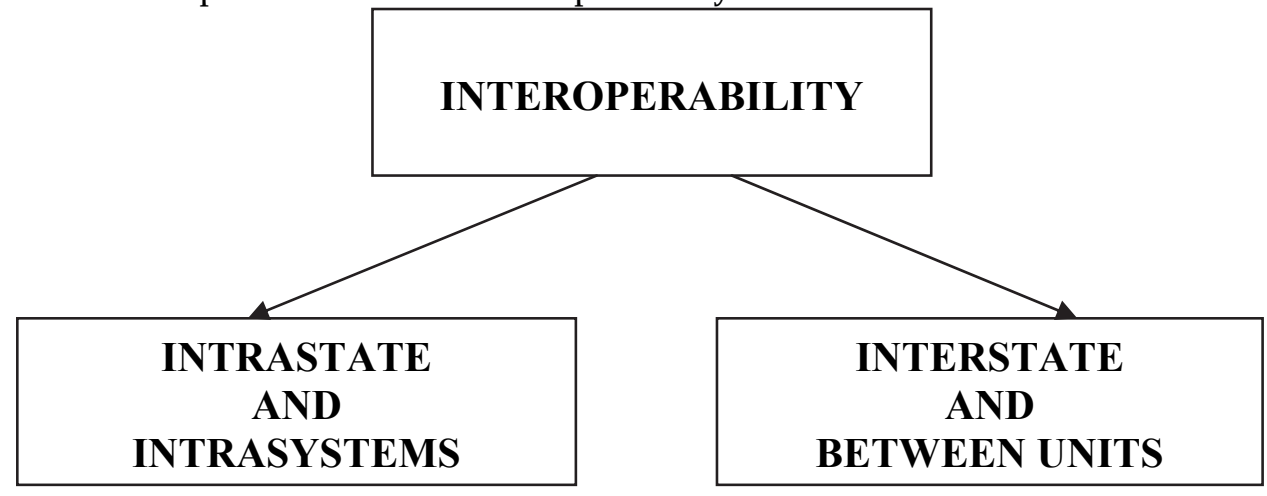


If structure and responsibilities can be established at the intrastate interoperability level, a very complex and comprehensive situation must be managed in order to achieve standards of interoperability at the interstate level. Most authors refer to this level of interoperability when explaining the functioning of NATO. Such interoperability is an element of the willingness of alliance or coalition members to work together over the long term to achieve and maintain shared interests against common threats. Alliance and coalition interoperability is one means of achieving both effective and efficient military capabilities: a rationalized approach to the interoperability can reduce alliance-wide military expenditures, increase flexibility, or define military niches that will be provided by national members so that redundancy can be avoided (Jamison, 2000: 9).

When presenting the Slovenian case study, both levels of interoperability are applicable. The national defense system of Yugoslavia, created on the two pillars, must be perceived as one intrastate system that should incorporate the theoretical fundaments of interoperability; however, this has never happened. Moreover, the federal system, based on the Yugoslav People's Army, was important, and to a certain level, an individual player in the defense system. The territorial defense of the Yugoslav republics might be understood as a non-integrated subsystem where even cooperation is questionable.

\section{REASONS FOR INTEROPERABILITY IN SLOVENIA 1990-1991}

In the Slovenian case, interoperability is presented at its operative and tactical level because it represented harmonization in the operation of three separate subsystems of the national security system at the time. The spatial elements of the army included Territorial Defence (TD), a militia organized in a military manner, and the supporting National Protection Forces (Narodna zaščita) and organizations active under the Civil Protection Service. Although the doctrine of General People's Defense planned for the involvement of the aforementioned elements in the process of defense, the particular tasks of these elements were very different-and even more so their equipment, armaments, and their respective doctrines of operation. Furthermore, there were some very important differences in the organization and coordination of the line of command. While the two subsystems of the National Protection Forces and militia (police) were part of the Ministry of the Interior, the TD and Civil Protection Service were under the command of the Ministry of Defence. These differences demanded extensive organizational efforts when the Slovenian political elite decided to establish interoperability among the aforementioned defense systems. The 
synergy alone, which was provided though interoperability, enabled success against a much stronger, better equipped, and better supported federal military system that was based on a long military tradition-the Yugoslav People's Army-and that threatened Slovenia's process of acquiring independence, and consequently, its separation from the Socialist Federal Republic of Yugoslavia and establishment of an independent state. The first democratic multi-party elections held in April 1990 were won by the coalition of new parties called the Democratic Opposition of Slovenia (DEMOS), with the program's implementation starting immediately after their victory. The dissolution of the Socialist/Communist social order in Yugoslavia took on a specific form and manifested as national liberation, the breaking down of the federal structure of the time into independent states.

Slovenian leadership strictly advocated the legalistic method of separation in line with the constitutional principle of self-determination, which was not accepted by the leaders of other republics, the army, and certainly not by the federal authorities. The problem of protecting the process of acquiring independence, which occurs within the framework of the military and security elements, was a significant and real problem. Since the security function was only partly provided for by the republics' authorities, and even less so by the military authorities, the Slovenian authorities had to begin the process of acquiring national independence by creating defense forces, at least to the extent possible. Since Slovenia was in a vulnerable position, the basic principle of new Slovenian leadership structures was to use every available defense capacity.

These were parts of the 20-year active defense system established under the General People's Defense, a unique Yugoslavian doctrine and defense system. ${ }^{1}$

${ }^{1}$ SLO was also conducted as a General People's Defense. This important difference shows that the understanding of doctrine wasn't enabled, even in the Yugoslav defense system. 
goslavia

Graph 2: Organizational chart of the national defense system of $\mathrm{Yu}$ -

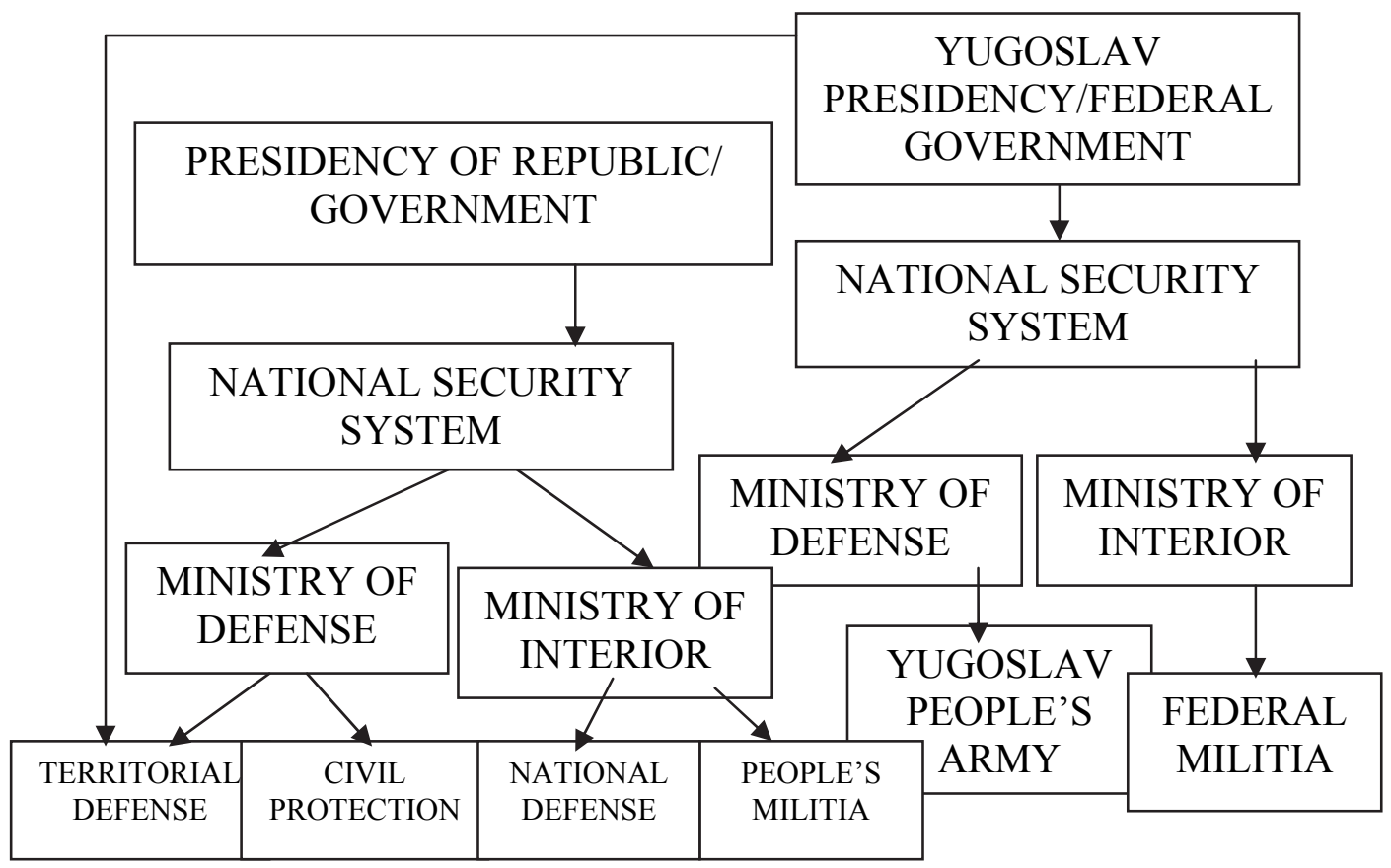

In forming such a defense system, the Slovenian elite based its work on experience acquired in 1990 when it simultaneously and secretly organized the Manoeuvre Structures of National Protection, a special resistance organization that united, based on the doctrine of General People's Defense, the TD, the militia, and other police forces that were intended to serve as a gendarmerie, which meant they would be trained for action in the military units. 
Graph 3: Slovene defense system in 1990

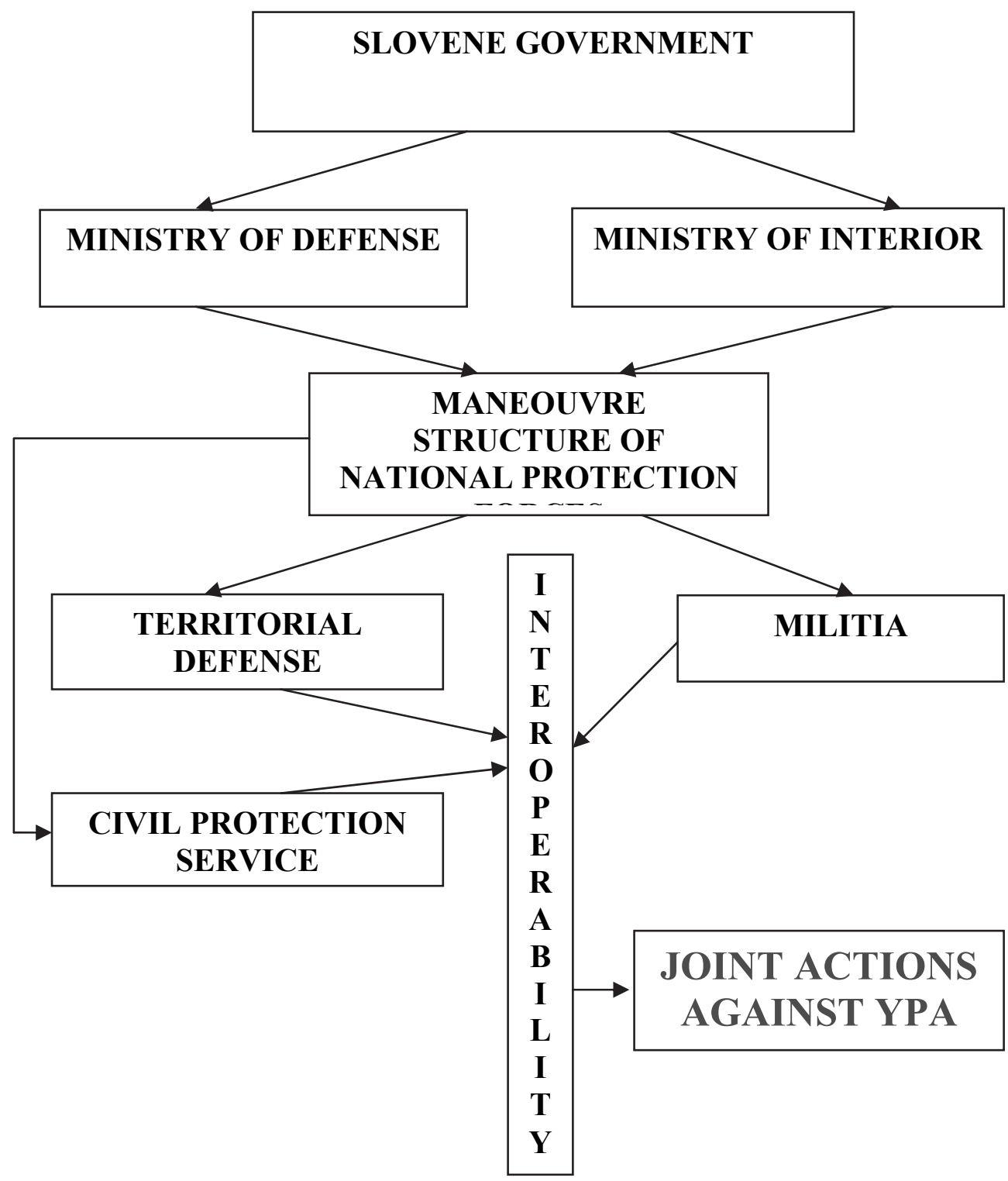

Based on the highly favorable result of the plebiscite held on December 23, 1990, in which $89 \%$ of the people voted for the creation of an independent Slovenian state, the republic's leaders planned for the formation of the independent state by June 26, 1991 (six months after the plebiscite). The strategic assessment of the risk of independence included 
the consideration of the significant possibility that the federal authorities would intervene with armed forces, namely the Yugoslav People's Army. For this reason, the republic's leaders prepared plans covering several different possibilities, the worst of which predicted the urgent need for defense against military intervention. The Slovenian Republic's leaders planned and included all available forces in the defense of the Republic of Slovenia: the TD, the militia, and the Civil Protection Service (civil defense). Each of these organizations had been a part of the Yugoslavian defense system, based on the doctrine of General People's Defense. This concept proved favorable as soon as the summer of 1990. The work of all three organizations was led and coordinated by a team established to act under special circumstances at both the national and regional levels. The team assumed defense command duties and included military and civilian experts (Kladnik et al., 2011: 101-102).

The standardization of the armament process was no problem thanks to the evenly distributed resources. All parts of the system were supplied with standardized weapons from the Yugoslavian defense system, which mostly included light infantry weapons and antitank equipment. This was improved little by the small quantities of imported infantry weapons and connection systems. Naturally, the distribution of supplies through segments was uneven and depended upon the different roles the segments played within the defense system. With awareness of its limitations in terms of armament, the Slovenian political and governmental elite, who were responsible for protecting the independence process, prepared a defense plan that promoted the use of passive defense in the event of any interventions, which meant blocking lines of traffic, setting up barricades, and blocking military barracks, with the use of arms limited to self-defense and urgent cases only. Strategically, the elite assessed that Slovenia would be in a much better position if the intervention were to occur after the independence process.

\section{DEFENSIVE INDEPENDENCE WAR IN SLOVENIA: INTEROPERABILITY IN PRACTICE}

On June 26, 1991, one day after the declaration of the independent state of Slovenia (the Republic of Slovenia), the Yugoslav People's Army indeed began to implement measures in response, and the Slovenian state leaders triggered their planned defense system. Contrary to expectations, the first measures of the Civil Protection Service were less successful than planned. The mere blocking of the Yugoslav People's Army units as the 
foundation of a passive defense strategy, without any fire support, soon proved less successful than expected.

Graph 4: Slovene Defense System in June 1991

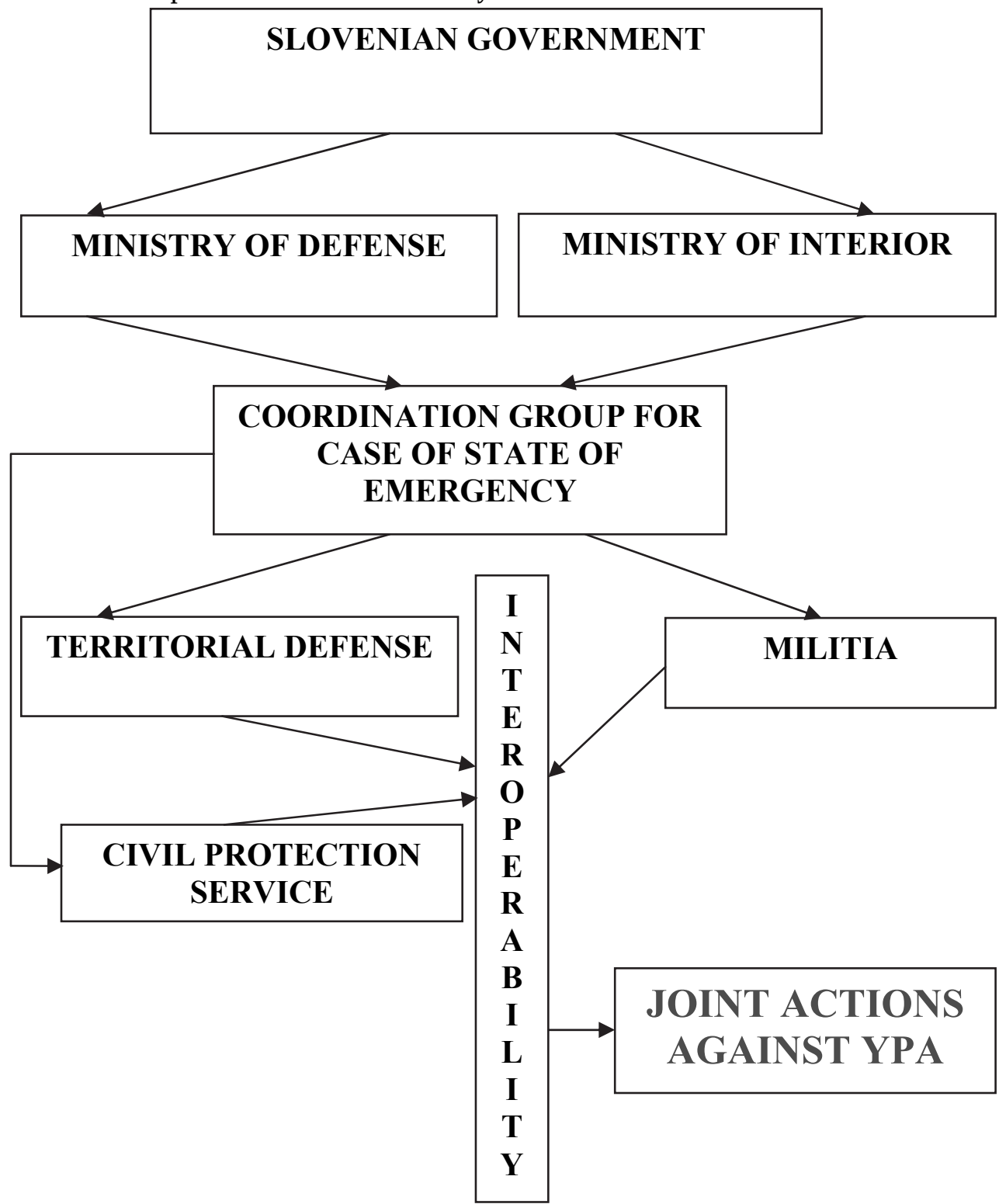

Nevertheless, all measures implemented in the course of the passive defense were effectively coordinated between the militia and TD units, as shown by the well-distributed blockades and barricades of all major traffic 
lines in the country. However, the measures for obstructing movement, which were not supported by arms, did not stop the progress of the YPA. For this reason, the Slovenian president, who was also the commander-inchief of the defense forces, decided on the morning of June 27, 1991 to use weapons to defend the newly proclaimed state (Kladnik et al., 2011:104-105).

Typically, the militia and TD forces operated together in combat. In its planning, the defense leadership of Slovenia envisaged a joint operation of units of the TD forces and the militia in case of intervention by the Yugoslav People's Army, before or after the declaration of independence, but it is not known whether they had also manufactured an operational scheme for their mutual operational performance. The defense leadership was relying on a well-known and established doctrine in regard to general national defense and civil protection, which had been in force within the Yugoslav armed forces since 1971. In case of military attack on the country, the leadership anticipated the establishment of territorial units in the occupied and unoccupied territory and the integration of police forces in the form of war militia units, to which all active and reserve militiamen were allocated by law. Their duties involved maintaining public law and order (Čepič et al., 2010: 75-76). In case of anti-special operations, the engagement of groups of one or more special military-organized militia units was planned in each of the 13 Interior administrations. In Slovenia, troops were grouped into seven battalions of a special forces militia, which at its smallest included 723 members and at its largest included 1392 members. The new democratic government, which took power after multi-party elections in the spring of 1990, maintained this defensive subsystem. In the autumn of 1990, the government upgraded the subsystem by establishing the special forces militia from previous militia units (Čepič et al., 2010: 72-75).

Since April 1991, the planning and coordination of Slovenian defense preparations has taken place within an emergency coordination group, which includes representatives of all three defense components (police, civil protection, and the TD) under the authority of the Ministry of the Interior. The establishment of this group was provided for by existing legislation from the country's socialist period. To ensure legality, the new government, in the context of defense (i.e., safety legislation), maintained the group's name and filled it with new members. Two months after the Slovenian president established a central group at the national level, in April 1991, it also established seven subgroups at the regional level at the end of May 1991. These subgroups were based on common platforms and coordinated the operational functioning of the defense forces, seven provincial headquarters of the TD, and seven administrations of the Interior, which were regional police headquarters (Kladnik et al., 2011: 101). 
The operational cooperation of the TD and the militia began immediately upon Slovenia's declaration of independence. Slovenia's plans to gain control of the borders of the new state were predicated on the shared features of both conflicting sides. Whereas the control and management of border crossings was within the jurisdiction of the militia, the police installed external signs to control the border crossings. Their first tasks were to replace flags and nameplates to signify the formation of a new country. The TD provided protection in the event of intervention by units of the YPA.

A special aspect of the interoperable operations of the Slovenian Armed Forces concerned cooperation between civil defense, police forces, and the TD. The Slovenian president included civil defense in Slovenia's defense plan, as well as guidelines for preparedness measures, on May 15, 1991. They foresaw the participation of civil defense in the disruptions of YPA maneuvers and the deliveries of military supplies. On June 27, 1991, a protection and rescue system was activated. Previous plans had predicted that the implementation of 50 major barricades and obstacles would disable the output and movement of YPA units from their barracks. The establishment of barricades and other obstacles was left to responsible road companies, each in its area of management, and they were planned by specific groups formed by the executive councils of municipalities. These interoperable operations were carried out only partially or with delay, so the police took matters into their own hands and created barriers. The power industry and postal companies were included in defense plans and were given the task of selectively and simultaneously disconnecting electricity and telephone service to YPA barracks and facilities. Both the Territorial Defense and the militia were involved in the blockade of military installations and their protection (Malešič, 2012: 223-225).

Conflicts with the advancing and primarily motorized or armored columns of YPA began in the morning of June 27, 1991, after the Slovenian president ordered the use of arms in the defense of the positions of the Slovenian Armed Forces on road communications (Kladnik et al., 2011: 105). The members of the militia played a primary role in the initial engagements of the armed forces. Due to better preparation, they more easily bore the psychological pressure of "the first shot," and more easily became acclimated to combat. As far as it was possible, groups were coordinated at the behest of the Republican leadership in various operational areas for which they were responsible, guided by the military and police forces, in combined operations (Kladnik et al., 2011: 107).

In Trzin (15 km NE of Ljubljana), the TD unit received the command to stop a YPA platoon on June 27, 1991 at midday. The platoon landed 
by helicopter about $15 \mathrm{~km}$ from the Brnik airport. The TO unit's mission was supported by a platoon comprised of members of the Special Forces militia, who participated with a TO platoon in the battle to fulfill specific purposes. During the battle, both units took the same tactical tasks; the Slovenian defense forces were successful, and the enemy unit gave up after a one-hour skirmish (Švajncer, 1997: 109-113; Gyergek, 2008; Kladnik et al., 2011: 328-332).

The blockade in Medvedjek ( $5 \mathrm{~km}$ NW of Trebnje), which stopped the advancing YPA column of armored vehicles from traveling from Novo Mesto to Ljubljana, was installed by about 380 soldiers from the militia and the TD. The confrontation took place on June 27, 1991 in the afternoon, when the armored vehicles, with anti-aircraft weapons (BOV), trucks, and air support, tried to break through the blockade. At this time, the Slovenian Armed Forces were not performing the same tasks during the combat as members of the militia, who set up and controlled the blockade and screened trucks from Ljubljana, while members of the TD protected their position on both sides of the road (Kladnik et al., 2011: 210-211). Members of the civil defense also mined the overpass above the raised roadblock. On June 28, 1991, the motorized YPA unit came to a halt in front of the barricade and then attempted to break through with air support. The planes machine-gunned vehicles that were part of the blockade and the surrounding targets, where TD forces should have been deployed. ${ }^{2}$ The Slovenian defense forces were successful in that the blockade column did not break, but the air attack caused the rapid withdrawal of the TD and the destruction of defense barriers (Švajncer, 1997: 44-54; Gole, 2011: 55-58, Kladnik et al., 2011: 210-213).

One of the most recent examples of the joint functioning of individual parts of the Slovenian defense forces was the fight for Holmec, which is situated on the Austrian-Slovenian border in Carinthia (10 km NW of Prevalje), on the morning of June 28. One day earlier, on June 27, a YPA unit was tasked with ambushing the border crossing from the guardhouse, which was $200 \mathrm{~m}$ away from the building housing the border controls. Police officers at the facility were called to leave the building, but they refused. After the ultimatum had expired, YPA soldiers attacked the border police station and severely damaged it with artillery fire. During the battle, a sniper killed two police officers and seriously wounded a third. Meanwhile, the main force of the TD and the militia intervened from Prevalje and were tasked with unblocking and encircling the guardhouse. Reinforcements were in defensive positions within 100-200 m from the facility.

\footnotetext{
${ }^{2}$ During machine-gunning, the aircraft killed seven truck drivers, who were present despite the call to evacuate (Cf. Kladnik et al., 2011: 211, 222).
} 
The morning attack on June 28 used the same tactical tasks for both militiamen, small groups of whom were assigned to TD units, and members of the TD. After a successful joint attack on the guardhouse and bombardment with $20 \mathrm{~mm}$ anti-aircraft guns, they forced most of the guardhouse crew to surrender and the commanding officer to withdraw. In addition to this cooperation in tactical procedures, members of the militia maintained communication with the joint operational headquarters in Slovenj Gradec and the TD headquarters; due to a lack of technical means (radio), communication between units of the TD were considered to be "cancer wounds" in terms of operational functionality (Prebilič and Gustin, 2008: 110; Korant, 2008: 43; Švajncer, 1993: 191-192).

In the evening of June 27, when the command operation, regarding the YPA presence in Slovenia, announced that the YPA had achieved most of its objectives and occupied most of the border crossings, the Slovenian leadership ordered focused attacks on the occupied border crossings and guardhouses. However, on June 28, the Slovenian defense forces also engaged in attacks on military depots situated on the border and the disarmament of deployed YPA members (Janša, 1992: 98).

In the June 28 attack on the tank column that had occupied the border crossing in Rožna Dolina ( $3 \mathrm{~km} \mathrm{~S}$ of Nova Gorica), two battle groups were used: one composed of members of the TD and another composed of members of special militia units (SMUs). Both groups had been tasked with surprise-attacking the border crossing and disabling the YPA unit, which was comprised of 117 soldiers and 5 tanks. By acting quickly and capturing the YPA's commanding officers, both units achieved the surrender of the YPA units (Kladnik et al., 2011: 366-369).

The regional headquarters in Nova Gorica employed two SMU units and three TD units to encircle and attack a border crossing in Vrtojba on June 28 1991. However, since the border crossing was in a clearing and it was difficult to conquer the command force, the units preferred to focus on negotiations, which were successful. In the evening of June 29, at 18:15, 138 soldiers with 7 tanks surrendered to militia forces (Kladnik et al., 2011: 369-372). On the same day, the SMU unit collaborated with the TD to block an intersection in Podmark ( $5 \mathrm{~km} \mathrm{~S}$ of Nova Gorica). Both units were given the same orders, but the commander of SMU took the leading role during the surrender of the stopped YPA vehicles (Kladnik et al., 2011: 373).

The militia and the TD were equally involved in capturing the barracks in Bovec on June 29, 1991. Both formations took starting positions for the attack, but the attack did not occur because the group occupying the barracks, consisting of members of both formations, managed to persuade the crew to surrender (Kladnik et al., 2011: 385-386). 
During the targeted attacks on border guardhouses, the tactics of the small units led to many opportunities for operational cooperation between military and police units. On June 28, 1991, out of 45 border guardhouses occupied by special YPA platoons (30-40 members), Slovenian defense forces attacked or surrounded at least 15. However, the composition of the forces was differently structured during these attacks. The attacks were performed mainly by TD units, though in many cases general military units and the SMU were utilized, demonstrating that units were chosen based on local conditions and needs. The SMU was apparently considered to be the same as qualified special purpose units or anti-diversion TD units, and was considered to be capable of working with them.

During the capture of the Dolga Vas border crossing, both unit formations participated in different ways. TD units surrounded the guardhouse next to the border crossing, and the militiamen defending the border crossing shot at the guardhouse and the troops alongside it after the ultimatum had expired.

After discontinuing bombardment, all 67 soldiers in the guardhouse surrendered (Kladnik et al., 2011: 416-417). A typical interoperable operation of the two branches, the Slovenian Armed Forces clashed while taking the guardhouse in Nova Vas (25 km W of Sežana). On July 1, 1991, at the urging of local observers and authorities, the SMU and two TD units were sent to storm the guardhouse. The SMU was given the same tasks at a central operating command and was assigned more specifically to advance the negotiations for the surrender of the commander of the guardhouse. The negotiations were unsuccessful. After a short fight during which the YPA commander fell, the guardhouse unit surrendered (Kladnik et al., 2011: 374). Many such attacks were cancelled due to expectations of negotiations for ceasefire. For example, on June 28, 45 TD district headquarters, together with the militia unit, prepared an attack on a border crossing at Fernetiči ( $2 \mathrm{~km} \mathrm{~W}$ of Sežana) using two TD platoons and a special police unit. Before the attack, the corps received notice of a general ceasefire and the attack was cancelled, though it was carried out later (Kladnik et al., 2011: 56 and 302).

The operational tasks were divided outside of combat actions. The typical role of the militia units was to achieve the surrender of individual YPA guardhouses and border units. Since the commanders of YPA border units believed reaching surrender agreements to be easier with militia units, they usually refused to negotiate with the TD, instead negotiating with militia commanders. Thus, the militia took a major role in the implementation of surrender agreements. TD units served as in-depth protection and primarily arranged the transport and collection of confiscated weapons and equipment. 
One of the most atypical surrenders is that of the Miren guardhouse ( $6 \mathrm{~km} \mathrm{~S}$ of Nova Gorica), on July 2, 1991. Based on agreements made regarding the surrender of the guardhouse, the SMU arrived at the building. The commander of the guardhouse was quite surprised because he wasn't even negotiating surrender, but he surrendered the guardhouse anyway. It was soon discovered that the original surrender concerned the crew of a neighboring guardhouse, located approximately $3 \mathrm{~km}$ away; the SMU was incorrectly directed (Kladnik et al., 2011: 375).

This low-intensity combat continued with occasional ceasefires until July 3, when the final ceasefire was declared. This ceasefire was extorted using diplomatic pressure from the European community. The conditions for armistice were formed by means of a joint statement including Yugoslavia, Slovenia, and Croatia, signed on July 8, 1991 in the Brioni Islands under the supervision of the European Troika.

Due to the low-intensity armed conflict, problems with interoperability were mostly manifested due to the (non-)application of identical tactical processes; the main two defense components were derived from two different operational doctrines. Before that, the tactical training of TD forces was mostly followed by territorial supervision and combat in the occupied territory, with the support of local inhabitants with regard to supplies and intelligence service provisions. The militia had at its disposal the planned formation of Special Police Units and Military Police Units, which united professional and reserve policemen. Its tactical assignments mainly concerned anti-specialist operations and the preservation of peace and order. As the police units were generally better trained than most TD unitsthe latter being mainly comprised of reserve forces-the former had to assume a more important role in initial defense combat than other forces and function as the main fighting element. Gradually, the TD adapted to war conditions and assumed a greater responsibility in combat. Other problems occurred due to different levels of supplying both parts of the units with connection equipment and weapons, as well as to different qualification levels of the members of the militia and TD. 
Vladimir Prebilić, Damijan Guštin

INTEROPERABILNOST U PRAKSI:

STUDIJA SLUČAJA SLOVENAČKI RAT ZA NEZAVISNOST 1991

\section{Rezime}

Tokom vojnog konflikta, koji je trajao deset dana, sva tri sastavna dela odbrambenih snaga Republike Slovenije, sinhronizovano delujući, uspešno su se oduprli mnogo snažnijoj i opremljenijoj vojsci Socijalističke Federativne Republike Jugoslavije, Jugoslovenskoj narodnoj armiji. Uprkos problemima koji su se pojavili kao rezultat neproverene interoperabilnosti, vojska, policija i pripadnici Teritorijalne odbrane delovali su zajedno, dobili bitku, strategijski pobedili JNA u Sloveniji i postigli povlačenje i raspuštanje njenih jedinica i garnizona u Sloveniji.

Ipak, napred pomenuti događaji su se desili tokom vojnog konflikta manjeg intenziteta, koji su dozvolili rezervnim snagama dovoljno vremena da se prilagode situaciji i milicijskim jedinicama da se uključe u svoje uloge, iako je situacija mogla biti drugačija da je konflikt imao viši intenzitet. Slovenačke odbrambene snage su usvojile i uspešno primenile jugoslovenski sistem odbrane, koji se bazirao na doktrini opštenarodne odbrane. Komandanti i komandiri su u borbi koristili različite vojne elemente, od kojih je svaki mogao doprineti u određenim situacijama. 